\title{
The Bungling of Justice Nadon's Appointment to the Supreme Court of Canada
}

Hugo Cyr

Follow this and additional works at: http://digitalcommons.osgoode.yorku.ca/sclr

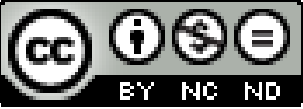

This work is licensed under a Creative Commons Attribution-Noncommercial-No Derivative Works 4.0 License.

\section{Citation Information}

Cyr, Hugo. "The Bungling of Justice Nadon's Appointment to the Supreme Court of Canada." The Supreme Court Law Review: Osgoode's Annual Constitutional Cases Conference 67. (2014).

http://digitalcommons.osgoode.yorku.ca/sclr/vol67/iss1/3 


\title{
The Bungling of Justice Nadon's Appointment to the Supreme Court of Canada
}

\author{
Hugo Cyr
}

\section{INTRODUCTION}

On April 22, 2013, the Honourable Justice Morris Fish wrote to the then Minister of Justice, the Honourable Robert Nicholson, to advise that he would retire from the Supreme Court of Canada and that his retirement would be effective August 31, 2013, a mere three months before he reached the mandatory retirement age. ${ }^{1}$ Despite four months' notice, the federal government waited until the last minute to appoint a replacement. Indeed, just a week before the Fall term hearings were to begin at the Supreme Court, the Prime Minister announced on September 30 that Justice Marc Nadon, a supernumerary judge of the Federal Court of Appeal, was his "nominee". ${ }^{2}$ Justice Nadon had been a member of the Quebec bar from 1973 to 1993 , practising mainly maritime law up until his appointment to the Federal Court, six months prior to the entry into force of the Civil Code of Québec in 1994. ${ }^{3}$

This rushed announcement came as a surprise because not long before, in mid-August, the Minister of Justice publicly recognized that there might be some problems in appointing a judge currently sitting on the Federal Court or the Federal Court of Appeal to the Supreme Court. In an interview published in the National Post, the Minister declared that

Full Professor, Faculté de science politique et de droit, Université du Québec à Montréal (UQAM), and member of the Quebec Bar.

Supreme Court, News Release (April 22, 2013), online: <http://scc-csc.lexum.com/scc-csc/ news/en/item/4282/index.do>. Justice Morris Fish was born on November 16, 1938. See Supreme Court of Canada, online: $\langle$ http://www.scc-csc.gc.ca/court-cour/judges-juges/bio-eng.aspx?id=morris-j-fish $>$.

2 Press Release: "Prime Minister Announces Nominee for the Supreme Court of Canada", September 30, 2013, online: <http://pm.gc.ca/eng/news/2013/09/30/pm-announces-nominee-supremecourt-canada>.

3 CCQ-1991. 
the Supreme Court Act ${ }^{4}$ needed to be updated because "[t]here are provisions right now that could be interpreted as excluding federal judges from Supreme Court appointments ...". 5 The fear that such an appointment might not be legally valid was quite real within the Justice Department. At least, it was real enough that it moved the Minister to seek legal opinions from two retired Supreme Court judges. According to answers given by the government to order papers in the House of Commons, ${ }^{6}$ an initial opinion was sought from retired Supreme Court Justice Louise Charron, who only gave an oral opinion ${ }^{7}$ - the content of which is not publicly available. Retired Supreme Court Justice Ian C. Binnie was later asked for a written opinion, which is dated September 9, 2013. ${ }^{8}$ That opinion predominantly examined whether or not a Federal Court judge could be appointed to the Supreme Court in light of section 5 of the Supreme Court Act ${ }^{9}$ and concluded that the same rule applied proprio motu to section 6 , dealing with the three seats reserved for judges from Quebec. The relevant sections read:

Who may be appointed judges

5. Any person may be appointed a judge who is or has been a judge of a superior court of a province or a barrister or advocate of at least ten years standing at the bar of a province.

\section{Conditions de nomination}

5. Les juges sont choisis parmi les juges, actuels ou anciens, d'une cour supérieure provinciale et parmi les avocats inscrits pendant au moins dix ans au barreau d'une province.

R.S.C. 1985 , c. S-26.

Tobi Cohen, "Peter MacKay insists Conservatives are not moving Canada toward U.S.-style justice", National Post, August 17, 2013, online: <http://news.nationalpost.com/2013/08/17/petermackay-insists-conservatives-are-not-moving-canada-toward-u-s-style-justice/>.

Order/Address of the House of Commons, Q-437, questions by Irwin Cotler, (Mount Royal), April 1, 2014, answers by Tom Lukiwski, May 26, 2014 [hereinafter “Order Paper, Q-437”].

$7 \quad I d$., answer (ii).

$8 \quad$ Ian C. Binnie, "Re: Eligibility of Federal Court Judges for Appointment to the Supreme Court of Canada", legal opinion, September 9, 2013, online: <http://pm.gc.ca/grfx/docs/20130930_ Binnie_cp.pdf>

$$
9^{-} \text {R.S.C. } 1985 \text {, c. S-26. }
$$


Three judges from Quebec

6. At least three of the judges shall be appointed from among the judges of the Court of Appeal or of the Superior Court of the Province of Quebec or from among the advocates of that Province. ${ }^{10}$
Représentation du Québec

6. Au moins trois des juges sont choisis parmi les juges de la Cour d'appel ou de la Cour supérieure de la province de Québec ou parmi les avocats de celle-ci.

Still unsure, the Justice Department sought the opinion of constitutional law expert Peter Hogg on Justice Binnie's analysis. ${ }^{11}$ The Honourable Louise Charron was also asked to comment on Justice Binnie's opinion. Both Louise Charron's and Peter Hogg's opinions were only conveyed orally to the government. ${ }^{12}$ The Prime Minister then took the extraordinary step of releasing to the public Justice Binnie's opinion, together with approving comments by Charron and Hogg, on the same day he announced Justice Marc Nadon's nomination.

Clearly, the government knew that the nomination was going to be controversial. We may assume that it is precisely because of the potential controversy that could ensue from such an appointment that the government took those extraordinary measures. However, they were not the right measures. And what the government subsequently did, despite receiving serious warnings to the contrary, only worsened the situation. If the federal government had been diligent, it would have referred the question to the Supreme Court first, appointed someone else in the meantime to replace Justice Fish, and if the answer came back positive from the Supreme Court, it could then have appointed Justice Marc Nadon to replace Justice Louis LeBel, who is due to retire at the latest in the Fall of 2014. Certainty would have been achieved at no cost to the credibility of the Supreme Court. Unfortunately, this is not the path the government chose and Quebec was deprived of one of its three constitutionally reserved Supreme Court judges for the entire 2013-2014 term.

Indeed, Justice Nadon was sworn in, his appointment was contested the very same day in the Federal Court and he recused himself until the

\footnotetext{
$10 \quad I d$.

11 Prime Minister News Backgrounder: "Qualification of a member of the Federal Court with 10 years of experience as a member of the Québec Bar to be appointed to the Supreme Court of Canada", September 30, 2013, online: <http:/www.pm.gc.ca/eng/news/2013/09/30/qualificationmember-federal-court-10-years-experience-member-quebec-bar-be>.

12 Order Paper, Q-437, supra, note 6, answers (ii), (jj), (kk), (mm), (nn) and (oo).
} 
issue was fully settled. Parliament rushed to amend the Supreme Court Act by attaching the proposed changes to a budgetary Bill, and the government referred the entire question to the Supreme Court. In an opinion handed down March 21, 2014, a majority of the Supreme Court (6:1) considered the appointment of Justice Nadon invalid. Quebec then had to wait approximately three more months before Justice Clément Gascon from the Quebec Court of Appeal was finally appointed by the federal government to replace Justice Fish.

The story I am about to tell is thus one of constitutional imprudence caused by political short-termism that unfortunately resulted in predictable damage to the workings of our federation. It is the sad chronicle of a series of decisions that do not reflect what is to be expected from true statesmanship. I will first address the formal process that led to the nomination of Justice Nadon (Part II). I will then turn to the challenges to Justice Nadon's appointment, the federal government's attempt at modifying the Supreme Court Act and the received warnings that it not only chose to ignore, but that it actively derided (Part III). I will then examine the Supreme Court's reference (Part IV), and some of the foreseeable constitutional consequences of the majority's opinion (Part V).

\section{THE PROCESS LEADING TO THE APPOINTMENT OF JUSTICE NADON}

First, the federal government may consult, and does consult, all sorts of stakeholders to establish a first "long list" of potential candidates. The Minister of Justice consulted with the Chief Justice of Canada, the Chief Justice of Quebec, the Chief Justice of the Quebec Superior Court, the Chief Justice of the Federal Court of Appeal, the Chief Justice of the Federal Court, the Attorney General of Quebec, the President of the Canadian Bar Association, the President of the Barreau du Québec, and other prominent members of the Quebec legal community to identify potential candidates. ${ }^{13}$ It transpired that during the consultations with the Chief Justice of the Supreme Court, the latter had specifically warned the Minister of Justice of possible problems with the appointment of a federal court judge on one of the three reserved seats for Quebec. ${ }^{14}$

\footnotetext{
$13 \quad I d$., answer (a).

14 The fact that the Chief Justice gave this particular warning to the government led to an ill-advised spat between the government and the Chief Justice two weeks after Justice Nadon's appointment had been invalidated. On May 1, 2014, senior Conservatives claimed that Chief Justice
} 
Once potential candidates agreed to submit their names for consideration on a confidential basis, the Minister of Justice and the Prime Minister's Office determined who should be included in the "long list" to be considered by the so-called "Selection Panel". Thus, the opinions of those who were consulted were not treated as binding -

Beverley McLachlin had lobbied against the appointment of Justice Nadon and then, when he was nonetheless appointed, invalidated his appointment (John Ivison, "Tories incensed with Supreme Court as some allege Chief Justice lobbied against Marc Nadon appointment" National Post (May 1, 2014), online: <http://news.nationalpost.com/2014/05/01/tories-incensed-with-supreme-court-as-some-allege-chiefjustice-lobbied-against-marc-nadon-appointment/>). Later that day, the Prime Minister's Office issued a statement to reporters suggesting that Chief Justice McLachlin had inappropriately attempted to call the Prime Minister to discuss the appointment of Justice Nadon (Tonda MacCharles, "PM refused to take 'inadvisable, inappropriate' call from chief justice, PMO says" The Toronto Star (May 1, 2014), online: <http://www.thestar.com/news/canada/2014/05/01/pm_refused_to_take_inadvisable_inappropriate_ call_from_chief_justice_pmo_says.html>). The Executive Legal Officer of the Supreme Court shot back immediately with a rare communiqué explaining what the Chief Justice had done (and not done) when consulted by the Minister of Justice on the appointment of a judge to replace retiring Justice Fish (Supreme Court of Canada, News Release, May 2, 2014):

On July 31, 2013, the Chief Justice's office called the Minister of Justice's office and the Prime Minister's Chief of Staff, Mr. Novak, to flag a potential issue regarding the eligibility of a judge of the federal courts to fill a Quebec seat on the Supreme Court. Later that day, the Chief Justice spoke with the Minister of Justice, Mr. MacKay, to flag the potential issue. The Chief Justice's office also made preliminary inquiries to set up a call or meeting with the Prime Minister, but ultimately the Chief Justice decided not to pursue a call or meeting.

The Chief Justice had no other contact with the government on this issue.

The Chief Justice provided the following statement: "Given the potential impact on the Court, I wished to ensure that the government was aware of the eligibility issue. At no time did I express any opinion as to the merits of the eligibility issue. It is customary for Chief Justices to be consulted during the appointment process and there is nothing inappropriate in raising a potential issue affecting a future appointment."

As Joan Bryden of the Canadian Press wrote, Minister of Justice Peter MacKay "escalated" the "feud" by suggesting that the Supreme Court's ruling on the validity of the appointment of Justice Nadon was not based on the rules of the Supreme Court Act as they existed prior to the ruling (Joan Bryden, "Peter MacKay escalates feud with Supreme Court's Beverley McLachlin", Canadian Press, available in The Toronto Star (May 5, 2014), online: <http://www.thestar.com/news/canada/2014/ 05/05/peter_mackay_escalates_feud_with_supreme_courts_beverley_mclachlin.html>). On May 6, 2014, the Leader of the Official Opposition, Thomas Mulcair, asked the Prime Minister, in the House of Commons, to "apologize to the chief justice and to Canadians for this unprecedented and, indeed, inexplicable attack on one of our most respected democratic institutions, the Supreme Court of Canada" (House of Commons Debates, 081 (May 6, 2014) (Hon. Thomas Mulcair)). The Prime Minister, without explicitly denying that the government had attacked the Supreme Court with its various statements, responded by saying $(i d$.):

Mr. Speaker, I categorically reject the premise of that question.

The fact is this. In terms of the eligibility question, it was my understanding that this was a matter that could go before the court. In fact, the government later referred the matter to the court. For that reason, I chose not to have a discussion with the court on that question, but instead to discuss it with independent legal experts, and we acted on their advice. (Id. (Right Hon. Stephen Harper)) 
contrary to the amendment to the Constitution proposed in the Meech Lake Agreement ${ }^{15}$ and the Charlottetown Accord $^{16}$ that would have made the short lists provided by provinces binding. The government has refused to indicate how many individuals appeared on the "long list". ${ }^{17}$

On June 11, 2013, the Justice Minister announced the creation of an ad hoc "Selection Panel" of parliamentarians composed of three Members of Parliament ("MPs") from the Government caucus and two from the Opposition parties to review the "long list" established by the Minister of Justice and the Prime Minister's Office. ${ }^{18}$ While composed of parliamentarians, this was not a committee of the Parliament, but a committee meant to assist the government in its selection process. In light of its function, it would appear more appropriate to call this panel a "pre-selection" committee. Indeed, this committee was tasked with reviewing and assessing the "long list" of candidates put forward by the Minister of Justice and to provide an unranked list of three candidates to the Prime Minister and the Minister of Justice for their consideration. The Panel "was asked to consider candidates for the Supreme Court position on the basis of merit and excellence". ${ }^{19}$ However, it is interesting to note that the panel was not merely composed of jurists. In fact, two out of three MPs from the government caucus who took part in the process leading up to Justice Nadon's appointment had no formal legal training. ${ }^{20}$

15 Section 6 of the Meech Lake Agreement (The 1987 Constitutional Accord, Ottawa, Ontario, June 3, 1987) would have added s. $101 \mathrm{C}$ to the Constitution Act, 1867 (U.K.), 30 \& 31 Vict, c. 3, reprinted in R.S.C. 1985, App. II, No. 5.

16 Section 19 of Charlottetown Accord (Consensus Report on the Constitution: Final Text, Charlottetown, Prince Edward Island, August 28, 1992).

${ }_{17}$ However, recently, The Globe and Mail has apparently been able to obtain a copy of the "long list" in question that allegedly would have contained six names. Four of those named on the list are federal court judges. See Sean Fine, "The secret short list that provoked the rift between Chief Justice and PMO" The Globe and Mail (May 23, 2014), online: <http://www.theglobeandmail.com/ news/politics/the-secret-short-list-that-caused-a-rift-between-chief-justice-and-pmo/article18823392/? page $=$ all $>$ [hereinafter "Fine, 'The secret short list"'].

18 Canada, Minister of Justice, News Release, "Minister of Justice Announces Members of the Supreme Court of Canada Selection Panel" (June 11, 2013), online: <http://news.gc.ca/web/ article-en.do?crtr.sj1D=\&crtr.mnthndVl=12\&mthd=advSrch\&crtr.dpt1D=6681\&nid=830869\&crtr. lc1D=\&crtr.tp1D=1\&crtr.yrStrtVl=2008\&crtr.kw=\&crtr.dyStrtVl=26\&crtr.aud1D=\&crtr.mnthStrtVl $=2 \&$ crtr.page $=9 \&$ crtr.yrndVl=2015\&crtr.dyndVl=31 $>$. The Panel was composed of Mr. Jacques Gourde (Conservative Party of Canada), Ms. Shelly Glover (Conservative Party of Canada), Mr. Robert Goguen (Conservative Party of Canada), Ms. Françoise Boivin (New Democratic Party of Canada), Hon. Dominic LeBlanc (Liberal Party of Canada).

19 Order Paper, Q-437, supra, note 6, answer (pp).

20 The Honourable Shelly Glover is a police officer. Her training relates to enforcement of the law, not interpretation of the law in various domains. Jacques Gourde is a farmer. 
And of the five members on the committee, only one was a Quebec lawyer trained in civil law. ${ }^{21}$ The Prime Minister and the Minister of Justice were then to select a nominee from that list.

The parliamentarians who took part in the pre-selection committee were bound by very strict confidentiality rules that prohibited them from divulging any information pertaining to the deliberations of the ad hoc preselection committee. Initially, we knew that they consulted the same stakeholders that the Minister of Justice had consulted when putting together, with the Prime Minister's Office, the "long list". 22 But since we did not know whether there were more than three names on the so-called "long list", and since the pre-selection committee could not suggest additional names, it was hard to evaluate the actual input of the committee members in the process. According to leaks published in The Globe and Mail, it now seems that the committee had to narrow down the pool of potential candidates from six to three. ${ }^{23}$ Also, confidentiality rules prohibit committee members from revealing whether or not the ultimate list of three candidates is the product of a consensus, or merely the result of a majority decision. ${ }^{24} \mathrm{In}$ other words, the Minister of Justice or the Prime Minister could have given the three government caucus members the mandate to ensure that one or another of the candidates on the long list gets to the short list and there is nothing that the representatives of the Opposition parties could have done about it. This very opaque process could end up merely providing

21 Françoise Boivin (NDP).

22 Ad hoc Committee on the Appointment of Supreme Court of Canada Justices, Peter MacKay (Minister of Justice), online: <http://www.justice.gc.ca/eng/news-nouv/ja-nj/2013/doc_ 32972.html> at 1310 :

The panel members also consulted extensively with members of the judiciary and the legal community, including the Chief Justice of Canada, the Chief Justice of Quebec, the Chief Justice of the Quebec Superior Court, the chief justices of the Federal Court and the Federal Court of Appeal, the Attorney General of Quebec, the Barreau du Québec, and the Canadian Bar Association.

23 Fine, "The secret short list", supra, note 17.

24 After the Supreme Court released its opinion on the validity of Justice Nadon's appointment, the Prime Minister, on April 1, 2014, surprisingly stated in the House of Commons that "during ... consultations, the NDP said that it did not object to appointing a Quebecker from the Federal Court to the Supreme Court", that "during consultations, all of the parties in the House agreed with the idea of appointing a Quebecer from the Federal Court to the Supreme Court" and that "the Liberal Party in fact supported the nominee for the Supreme Court" (House of Commons Debates, 066 (April 1, 2014) (Right Hon. Stephen Harper). However, the Prime Minister did not participate in those consultations and all of those who did were bound by a confidentiality agreement "not to disclose any information to anyone except to members and staff of the Selection Panel, the Commissioner or Deputy Commissioner for Federal Judicial Affairs, the Judicial Affairs Advisor to the Minister of Justice or the Minister of Justice" (Order Paper, Q-437, supra, note 6, answer (ss)). 
cover - offering the patina of legitimacy - to the government's decision. It is not the case that the rules ensure that manipulations will occur, but they do nothing to prevent them either.

It now appears that at least one judge from a federal court had to be on the pre-selection committee final list, as apparently four of the six candidates on the "long list" were such judges. ${ }^{25}$ In fact, according to Sean Fine of The Globe and Mail, the final decision of the pre-selection committee was not unanimous and two out of three candidates who made it to the final list were judges of the Federal Court of Appeal. ${ }^{26}$

While pre-selection committee members may have had all summer long to process the files of each candidate on the "long list", it would have been better to begin the process ahead of time knowing that Justice Fish had to retire no later than November 2013. This is particularly true in light of the quantity of information that needs to be processed. Indeed, each file contained the candidates' résumés, five decisions submitted to the pre-selection committee by the candidates themselves, ${ }^{27}$ as well as a full list of their reported decisions since their appointment to the Bench. ${ }^{28}$ MPs on the committee, bound by the confidentiality agreement, could not seek external assistance to analyze and review the general corpus of precedents of each candidate. They may have received help from the Office of the Commissioner for Federal Judicial Affairs Canada, but they could not rely on their own advisors to independently review all previous decisions by each of the candidates on the "long list".

This system creates an unfair asymmetry of information in favour of the government which put together the "long list". Indeed, the government

25 Fine, "The secret short list", supra, note 17.

26 Id.

27 The first question asked in the Order/Address of the House of Commons, Q-239, questions by Irwin Cotler, (Mount Royal), January 27, 2014, answers by Tom Lukiwski, March 24, 2014 [hereinafter "Order Paper, Q-239"] is introduced by this preamble:

With regard to the appointment to the Supreme Court of Justice Marc Nadon, and the information provided to MPs on the ad hoc.committee and available on the website of the Office of the Commissioner for Federal Judicial Affairs Canada which notes that "Each candidate was asked to identify five decisions for particular consideration by the Panel, preferably dealing with issues coming within the usual scope of the Supreme Court of Canada. ... As far as possible, the choice of five decisions was to reflect at least one of each of the following areas of law: constitutional law (Charter or federalism), criminal law (or national security), civil law, administrative law, and the candidates' choice": (a) how was this list of areas of law developed ...

The answer implicitly confirms such information: "The list of areas of law was intended to reflect issues coming within the scope of the Supreme Court of Canada - one category was left to the candidate's personal choice".

$28 \quad I d$., answer (h), (1) (ii), (v) and (vi). 
has the necessary resources to analyze all the past decisions of each candidate it decides to put on its "long list", while the members of the pre-selection committee - who are not necessarily legally trained have access to limited resources to complete their task. This affects the legitimacy of the process. However, Opposition parties found themselves in a catch-22 situation: if they took part in the process, they gave legitimacy to a skewed process; if they did not, they could later be accused of not caring about who gets appointed to the Supreme Court. Refusing to participate in the process — the empty-chair policy clearly has both pros and cons.

At any rate, following reception of the Committee's Report, Prime Minister Harper announced on September 30, 2013 that Justice Nadon (who was not on the list of names proposed by the Attorney General of Quebec $^{29}$ ) was his nominee to fill one of the three seats reserved for Quebec judges by section 6 of the Supreme Court Act.

Two days later, Justice Nadon appeared before another ad hoc committee made of parliamentarians - again, not an official House committee - to answer general questions about himself and his career. This meeting was public and questions dealing with substantive legal issues that may arise in the course of a case were deemed out-of-bounds. This was not a "confirmation" hearing in the American sense; the ad hoc committee had no decision power, nor the power to make any recommendation to the government regarding the appointment.

On October 3, 2013, by Order in Council P.C. 2013-1050, Justice Nadon was officially named Supreme Court judge and was sworn in on October 7, 2013.

\section{The ChALlENGES TO THE APPOINTMENT OF JUSTICE NADON AND THE FEDERAL GOVERNMENT'S REACTIONS}

A few hours after Justice Nadon had been sworn in, the appointment was being challenged in the Federal Court by Toronto lawyer Rocco

\footnotetext{
29 Bertrand St-Arnaud, then Quebec's Minister of Justice, had presented a list of four names to his federal counterpart, none of which was a judge appointed to a federal court (Paul Journet, "Le Québec lésé par le retrait du juge Nadon, dénonce Cloutier" La Presse (October 9, 2013), online: $<$ http://www.lapresse.ca/actualites/national/201310/09/01-4698047-le-quebec-lese-par-le-retrait-dujuge-nadon-denonce-cloutier.php>).
} 
Galati. ${ }^{30}$ Within less than 24 hours, the Supreme Court issued a statement declaring that Justice Nadon had decided "not to participate for the time being in matters before the Supreme Court of Canada". 31

Scholars quickly got busy examining the federal government's interpretation of sections 5 and 6 of the Supreme Court Act and came out with serious doubts about the government's claims. Paul Daly's blog ${ }^{32}$ on October 9 was probably the first to take a substantive look at the issues. It was quickly followed by Michael Plaxton and Carissima Mathen's paper that initially came out on the Social Science Research Network on October 23, and was later published in Constitutional Forum. ${ }^{33}$ Daly, Plaxton and Mathen concluded that while section 5 allowed for the appointment of Federal Court judges to the Supreme Court, section 6 is worded differently and was meant to set additional criteria for the appointment of the three judges representing Quebec on the Bench.

The basic argument against the validity of Justice Nadon's appointment to the Supreme Court boiled down to this: section 5 sets the basic requirements that the appointees may be persons who are or have been judges of a superior court of a province, or they may also be current or former lawyers who have been standing at the bar of a province for at least 10 years. For section 6 appointments, only candidates who are currently judges of the Court of Appeal or of the Superior Court of the Province of Quebec, or current members of the Quebec bar would be eligible. The textual arguments in favour of such a reading are supported by the framers' intent to ensure that the section 6 appointees have contemporary connection to the civil law tradition of Quebec in order to adequately represent its legal traditions and social values.

The Quebec government, on October 17, declared that it was examining different scenarios to challenge the appointment: a reference

30 Galati et al. v. The Right Honourable Stephen Harper et al., Federal Court of Canada, File No. T-1657-13. See Reference re Supreme Court Act, ss. 5 and 6, [2014] S.C.J. No. 21, 2014 SCC 21, at para. 10 (S.C.C.) [hereinafter "Supreme Court Reference (2014)"].

Supreme Court of Canada, News Release, October 8, 2013, online: <http://scc-csc. lexum.com/scc- csc/news/en/item/4401/index.do>.

32 Paul Daly, "Eligibility to sit on the Supreme Court of Canada" Administrative Law Matters (October 9, 2013), online: <http://administrativelawmatters.blogspot.ca/2013/10/eligibilityto-sit-on-supreme-court-of.html >; Paul Daly, "More on section 6 of the Supreme Court Act: Legislative History and Purpose" Administrative Law Matters (October 16, 2013), online: <http://administrativelawmatters.blogspot.ca/2013/10/more-on-section-6-of-supreme-court-act.html>.

33 Michael Plaxton \& Carissima Mathen, "Purposive Interpretation, Quebec, and the Supreme Court Act" (2013) 22:3 Constitutional Forum 15, initially made public online: <http://papers.ssrn.com/sol3/papers.cfm?abstract_id=2344452>. 
to the Quebec Court of Appeal, joining Galati's court challenge, adoption of a motion by the National Assembly, etc. ${ }^{34}$ The main focus of Quebec's opposition was that Justice Nadon did not seem to qualify under section 6 of the Supreme Court Act to be one of the three judges representing Quebec at the Court, as he was not a judge of the Court of Appeal or Superior Court of Quebec, nor a current member of the Quebec Bar.

The federal government was, at precisely that time, under significant pressure due to having appointing senators who appeared to have acted wrongfully. It did not want to deal with another appointment misfire. To try to quickly shut down challenges to Justice Nadon's appointment, on October 22, the government introduced two sections in its omnibus budgetary implementation Bill designed to "declare" that anyone who had been a member for at least 10 years of a provincial bar - and for section 6, the Bar of Quebec - qualified to become a Supreme Court judge. ${ }^{35}$ Simultaneously, the government launched a reference to the Supreme Court to determine the meaning of sections 5 and 6 of the Supreme Court Act and to confirm the validity of the so-called "declaratory" provisions that it was about to adopt in its budget bill. ${ }^{36}$

34 Patrick Bergeron, "Cour suprême: Québec va contester la nomination de Marc Nadon" La Presse, October 17, 2013, online: <http://www.lapresse.ca/actualites/justice-et-affaires-criminelles/ 201310/17/01-4700699-cour-supreme-quebec-va-contester-la-nomination-de-marc-nadon.php >.

35 Economic Action Plan 2013 Act, No. 2, S.C. 2013, c. 40, ss. 471, 472 (Bill C-4). The clauses read:

471. The Supreme Court Act is amended by adding the following after section 5:

5.1 For greater certainty, for the purpose of section 5 , a person may be appointed a judge if, at any time, they were a barrister or advocate of at least 10 years standing at the bar of a province.

472. The Act is amended by adding the following after section 6 :

6.1 For greater certainty, for the purpose of section 6 , a judge is from among the advocates of the Province of Quebec if, at any time, they were an advocate of at least 10 years standing at the bar of that Province.

36

Order in Council, P.C. 2013-1105.
471. La Loi sur la Cour suprême est modifiée par adjonction, après l'article 5 , de ce qui suit:

5.1 Pour l'application de l'article 5 , il demeure entendu que les juges peuvent être choisis parmi les personnes qui ont autrefois été inscrites comme avocat pendant au moins dix ans au barreau d'une province.

472. La même loi est modifiée par adjonction, après l'article 6 , de ce qui suit:

6.1 Pour l'application de l'article 6, il demeure entendu que les juges peuvent être choisis parmi les personnes qui ont autrefois été inscrites comme avocat pendant au moins dix ans au barreau de la province de Québec. 
The Quebec government intervened in the reference three days later, on October 25. This intervention might have been perceived as being purely motivated by the sovereigntist ideology and political calculations of the Parti Québécois, which was then forming a minority government. However, on October 29, the National Assembly adopted a unanimous motion to the effect that it (1) recalls that at least three judges of the Supreme Court must be taken from judges sitting at the Court of Appeal or Superior Court of Quebec, or from among current members of the Quebec Bar; (2) recalls that this constitutional guarantee is meant to safeguard Quebec's specificity and its civil law, and that it cannot be modified without the National Assembly's consent; (3) recalls that Quebec's historical position has been that those three judges ought to be selected from among the candidates suggested by the Attorney General of Quebec; (4) recalls that it is important that the three judges from Quebec be present when the Supreme Court hears major cases involving Quebec; (5) deplores the federal government's unilateralism in appointing the last judge from Quebec; (6) deplores that the Prime Minister's decision has led to the challenging of the said judge, forcing him to temporarily withdraw, thus depriving Quebec of one-third of its representation on the Supreme Court. ${ }^{37}$ In other words, a unanimous National Assembly rejected Justice Nadon's appointment to one of the three seats reserved to ensure the "représentation du Québec" - these are the very words of the French version of the Supreme Court Act.

37 Journal des débats de l'Assemblée nationale, 40th Leg., 1st Sess., Vol. 43, No. 84 (October 29, 2013):

Que l'Assemblée nationale rappelle que la Loi sur la Cour suprême confère au Québec trois juges à la Cour suprême et que ceux-ci doivent être choisis parmi les juges de la Cour d'appel ou de la Cour supérieure du Québec ou parmi les avocats en exercice, membres du Barreau du Québec;

Qu'elle rappelle que cette garantie constitutionnelle préserve la spécificité québécoise et civiliste et ne peut être altérée ou autrement modifiée sans le consentement de l'Assemblée nationale du Québec;

Qu'elle rappelle la position historique du Québec selon laquelle [...] trois juges du Québec à la Cour suprême devraient être sélectionnés parmi les candidats recommandés par le Procureur général du Québec au gouvernement fédéral:

Qu'elle rappelle l'importance que la Cour suprême puisse compter trois juges du Québec lors de l'audition de causes majeures pour le Québec;

Qu'elle déplore l'unilatéralisme dont a fait preuve le gouvernement fédéral lors de la nomination du dernier juge du Québec à la Cour suprême;

Qu'elle déplore que la décision du premier ministre du Canada ait mené à la contestation de la nomination de ce juge, ainsi qu'au retrait temporaire de ce dernier, ce qui prive actuellement le Québec du tiers de sa représentation à la Cour suprême. 
Rocco Galati's court challenge had already been a major blow to the process, but the intervention of the Québec government was probably a fatal one. While Galati's challenge showed that the legal case for Justice Nadon's appointment was not watertight, thus raising questions about the legal legitimacy of a judge appointed at the apex of the justice system, the unanimous rejection by the elected representatives of Quebec of the judge who was meant to ensure the representation of the Province at the Supreme Court cast a long shadow over his political legitimacy. Judges not wielding the power of the sword, or the power of the purse, depend on tacit acceptance of their legitimacy to ensure that their decision will be enforced. The unanimous motion of the National Assembly may well have proved to be the kiss of death to this appointment. Indeed, it may have been hard for Justice Nadon to recover from it. From then on, how could he ever benefit from the unquestioned legitimacy required to hear cases opposing the Quebec government to its federal counterpart? By saying this, I certainly do not mean to question Justice Nadon's personal integrity and sincere impartiality, but rather to suggest this raised a major problem of political perceptions. If Justice Nadon's appointment had been confirmed, he would have been labelled in Quebec "the SupremeCourt-judge-representing-Quebec-against-its-will". This would have played straight in the hands of the nationalists who are pleased to repeat since Duplessis that the Supreme Court is like the Pisa Tower; always leaning towards Ottawa. ${ }^{38}$

Of course, by then, it was too late for the federal government to cancel Justice Nadon's appointment. He had already been sworn in and he certainly could not have been impeached. Justice Nadon alone could have decided to resign. However, at that point, the federal government could have tried to mitigate its potential losses by simply letting the Supreme Court decide on whether or not the appointment was consistent with sections 5 and 6 of the Supreme Court Act and by dropping its attempt to modify the Supreme Court Act. That way, if Justice Nadon's appointment had been confirmed, he would have been able to sit without having to support the extra burden on his perceived legitimacy that his appointment was retroactively made valid by changing the rules of the game. And if his appointment were to be declared invalid by the Supreme Court, the latter would not have to expound on the controversial

38 Florian Sauvageau, et al., La Cour suprême du Canada et les médias: à qui le dernier mot? (Québec: Presses Université Laval, 2006), at 133-34. 
meaning of the amending formulas dealing with the Supreme Court and its composition.

Indeed, up until the decision came down in the Supreme Court Reference (2014), it was unclear whether or not the existence of the Supreme Court and its composition were already entrenched. This left open a significant amount of space for negotiations and cooperation at a sub-constitutional level between governments on such issues. However, by adopting the amendments to the Supreme Court Act ${ }^{39}$ declaring that a judge having been a member of the Quebec Bar for at least 10 years at any point in his or her life was sufficient to qualify for appointment, the government took a huge gamble. The amendment meant that if the Court were to disagree with the federal government's reading of sections 5 and 6 as they initially stood, the Court would then be forced to examine the constitutionality of the amendment before determining if it validated retroactively the appointment. And, while examining the constitutionality of the amendment, the Court might very well determine that certain parts of the Supreme Court are now entrenched and can no longer be modified legislatively - thus closing down the opportunity for sub-constitutional arrangements, and opening up the problem of distinguishing between the parts of the Supreme Court that are entrenched from those that are not.

The government had been publicly warned of such risks - and of additional ones! During the hearings of the Standing Committee on Justice and Human Rights that was tasked with examining the sections of the omnibus Bill that were meant to modify the Supreme Court Act, many witnesses told the MPs that this course of action was a risky one for several reasons. For example, Carissima Mathen testified to the effect that section 6, according to its purpose and legislative intent, did not allow for the appointment of a Federal Court judge to one of Quebec's three reserved seats. She also warned that if the Supreme Court were to consider it entrenched, this would "constrain the potential scope of any declaratory legislation". ${ }^{40}$ The government caucus MPs reacted with scoffs.

Paul Daly nonetheless testified in Standing Senate Committee on Legal and Constitutional Affairs to the same effect: "Although the Supreme Court Act does not form part of the Constitution of Canada, the Supreme Court of Canada may well conclude, in the face of unilateral Parliamentary action, that certain core provisions of the Supreme Court

39 Royal Assent was given on December 12, 2013. See S.C. 2013, c. 40.

40 Canada, House of Commons, Standing Committee on Justice and Human Rights, 41st Parl., 2nd Sess., No. 5, November 19, 2013 (Carissima Mathen, witness). 
Act, or certain essential and fundamental characteristics of the Supreme Court of Canada, are constitutionally entrenched and beyond the powers of Parliament." ${ }^{, 41}$ Daly also testified that he did not believe that section 6 allowed for the appointment of a Federal Court judge as one of the three representatives of Quebec. He astutely remarked that Justice Gerald Le Dain, a civil law lawyer, had been appointed to the Supreme Court from the Federal Court of Appeal, but not as a section 6 judge. Indeed, when he was appointed to the Bench, he took over the position of Justice Dickson, who had been appointed to replace Chief Justice Laskin, who had died. Justices Beetz, Chouinard and Lamer were already there as section 6 judges. In fact, all former Federal Court judges who have ever been appointed to the Supreme Court had only been section 5 judges and nothing barred a jurist from Quebec from being appointed to one of those positions. Justice Arbour was born in Montreal and she studied law at the Université de Montréal. Justice Bastarache was in the same class as Justice Arbour at the Faculty of Law of the Université de Montréal. Neither of them was considered to be a section 6 judge.

Adam Dodek testified in the Standing Committee on Justice and Human Rights that in his opinion, "clauses 471 and 472 [of Bill C-a] are not a proper subject of a budget bill; second, by bringing a reference to the Supreme Court about these very provisions, the government is interfering with the proper work of [the] House [of Commons]". ${ }^{42}$ The first point that Professor Dodek made was a very important one. He was referring to what I have taken to calling "Christmas-tree Bills"; Bills that are not mere omnibus Bills, but rather budgetary bills to which the government hangs unrelated matters. Such Bills have been prohibited since at least the 18th century in the Parliament of Westminster. Dodek believed that what was "at stake here is no less than the democratic features of the House of Commons. Bills such as this one are a threat to democracy in Canada." It is true that he did not say that such bundling of unrelated non-financial issues into a budget Bill was, strictly speaking, unconstitutional. However, I personally did go as far as that when I testified before the Standing Committee. ${ }^{43}$

\footnotetext{
41 Canada, Senate, Proceedings of the Standing Senate Committee on Legal and Constitutional Affairs, 41st Parl., 2nd Sess., Issue 1, Evidence, November 21, 2013 (Paul Daly, witness).

42 Canada, House of Commons, Standing Committee on Justice and Human Rights, 41st Parl., 2nd Sess., No. 5, November 19, 2013 (Adam Dodek, witness).

${ }_{43}$ Canada, House of Commons, Standing Committee on Justice and Human Rights, 41 st Parl., 2nd sess., No. 5, November 21, 2013 (Hugo Cyr, witness).
} 
Indeed, in my own testimony, I told the Standing Committee that I did not believe that section 6 allowed for the appointment of a Federal Court judge, that I did not believe that sections 471 and 472 were merely declaratory, that the proposed modifications ran the risk of being in violation of section 41(d) of the Constitution Act, 1982, ${ }^{44}$ and finally, that the Supreme Court may find that "Christmas-tree Bills" violate the entrenched constitutional principles of "parliamentary democracy" 45 and "responsible government". ${ }^{46}$ I thus advised the Standing Committee that, if Parliament truly wanted to adopt its intended changes to the Supreme Court Act, the federal government should (1) negotiate the amendment it sought with the provinces; and (2) put it in a separate bill. Knowing that the chances of coming up with an agreement with the provinces on the intended changes in the very short term were close to nil, the more prudent course of action for the federal government would have been to drop the intended amendment, and simply hope that the Supreme Court would validate the appointment on the basis of what the Minister of Justice thought was the right interpretation of the Supreme Court Act. But sadly, that is not what the government did.

44 Schedule B to the Canada Act 1982 (U.K.), 1982, c. 11.

45 See among others: New Brunswick Broadcasting Co. v. Nova Scotia (Speaker of the House of Assembly), [1993] S.C.J. No. 2, [1993] 1 S.C.R. 319 (S.C.C.); Harper v. Canada (Attorney General), [2000] S.C.J. No. 58, [2000] 2 S.C.R. 764, at para. 20 (S.C.C.), per Major J., dissenting; Cooper v. Canada (Human Rights Commission), [1996] S.C.J. No. 115, [1996] 3 S.C.R. 854 (S.C.C.), Lamer C.J.C.; Harvey v. New Brunswick (Attorney General), [1996] S.C.J. No. 82, [1996] 2 S.C.R. 876, at para. 68 (S.C.C.), L'Heureux-Dubé and McLachlin JJ.; R.W.D.S.U. v. Dolphin Delivery Ltd., [1986] S.C.J. No. 75, [1986] 2 S.C.R. 573, at para. 15 (S.C.C.); Switzman v. Elbling, [1957] S.C.J. No. 13, [1957] S.C.R. 285, at 326 (S.C.C.), per Abbott J.

${ }_{46}$ R. v. Curr, [1972] S.C.J. No. 66, [1972] S.C.R. 889, at 899 (S.C.C.) (quote cited with approbation in R. v. Burnshine, [1974] S.C.J. No. 73, [1975] 1 S.C.R. 693 (S.C.C.), Martland J. for the majority); Bliss v. Canada (Attorney General), [1978] S.C.J. No. 81, [1979] 1 S.C.R. 183 (S.C.C.); R. v. MacKay, [1980] S.C.J. No. 79, [1980] 2 S.C.R. 370 (S.C.C.); Canada (Commission des droits de la personne) v. Canada (Attorney General), [1982] S.C.J. No. 3, [1982] 1 S.C.R. 215 (S.C.C.); R. v. Beauregard, [1986] S.C.J. No. 50, [1986] 2 S.C.R. 56 (S.C.C.) (majority); Operation Dismantle Inc. v. Canada, [1985] S.C.J. No. 22, [1985] 1 S.C.R. 441, at para. 104 (S.C.C.); Reference re Remuneration of Judges of the Provincial Court of Prince Edward Island; Reference re Independence and Impartiality of Judges of the Provincial Court of Prince Edward Island, [1997] S.C.J. No. 75, [1997] 3 S.C.R. 3, at para. 139 (S.C.C.), the Chief Justice for the majority of eight judges. See also Reference re Criminal Law Amendment Act, 1968-69 (Canada), S. 16, [1970] S.C.J. No. 38, [1970] S.C.R. 777 (S.C.C.); Ontario Public Service Employees' Union v. Ontario (Attorney General), [1987] S.C.J. No. 48, [1987] 2 S.C.R. 2 (S.C.C.); Osborne v. Canada (Treasury Board), [1991] S.C.J. No. 45, [1991] 2 S.C.R. 69 (S.C.C.); Re Eurig Estate, [1998] S.C.J. No. 72, [1998] 2 S.C.R. 565 (S.C.C.); Figueroa v. Canada (Attorney General), [2003] S.C.J. No. 37, 2003 SCC 37, [2003] 1 S.C.R. 912 (S.C.C.); 620 Connaught Ltd. v. Canada (Attorney General), [2008] S.C.J. No. 7, 2008 SCC 7, [2008] 1 S.C.R. 131 (S.C.C.); Mining Watch Canada v. Canada (Fisheries and Oceans), [2010] S.C.J. No. 2, 2010 SCC 2, [2010] 1 S.C.R. 6 (S.C.C.). 


\section{THE SUPREME COURT REFERENCE (2014)}

The reference questions that were asked by the Government to the Supreme Court were:

1. Can a person who was, at any time, an advocate of at least 10 years standing at the Barreau du Québec be appointed to the Supreme Court of Canada as a member of the Supreme Court from Quebec pursuant to sections 5 and 6 of the Supreme Court Act?

2. Can Parliament enact legislation that requires that a person be or has previously been a barrister or advocate of at least 10 years standing at the bar of a province as a condition of appointment as a judge of the Supreme Court of Canada or enact the annexed declaratory provisions as set out in clauses 471 and 472 of the Bill entitled Economic Action Plan 2013 Act, No. $2 ?^{47}$

\section{The Majority Opinion on the Interpretation of Sections 5 and 6 of the Supreme Court Act}

Six of the seven judges who heard the case ${ }^{48}$ concluded that a judge of the Federal Court or Federal Court of Appeal is ineligible for appointment to the Supreme Court of Canada under section 6 of the Supreme Court Act. While section 5 sets out the general conditions of eligibility for appointment - one has either to be (1) a current judge of a superior court, or court of appeal, of a province; (2) a former judge of such courts; (3) a current lawyer of at least 10 years' standing at the Bar of a province; or (4) a former lawyer of at least 10 years' standing section 6 narrows the pool for judges appointed to represent Quebec by adding requirements. Only (1) current judges of the Superior Court or Court of Appeal of Quebec; and (2) current members of the Barreau du Québec are eligible under section 6 of the Supreme Court Act. In other words, section 6 adds two specifications: (1) that the status as a judge or as a member of the Bar must be current; and (2) the courts and Bar in question have to be Quebec's. The majority summarized their reasons for their interpretation of the requirements of section 6 as follows:

We come to this conclusion for four main reasons. First, the plain meaning of s. 6 has remained consistent since the original version of

$47 \quad$ Supra, note 36.

48 Justice Rothstein, having himself been elevated from the Federal Court of Appeal to the Supreme Court, did not take part in the proceedings. He is not a s. 6 judge. 
that provision was enacted in 1875 , and it has always excluded former advocates. Second, this interpretation gives effect to important differences in the wording of ss. 5 and 6. Third, this interpretation of s. 6 advances its dual purpose of ensuring that the Court has civil law expertise and that Quebec's legal traditions and social values are represented on the Court and that Quebec's confidence in the Court be maintained. Finally, this interpretation is consistent with the broader scheme of the Supreme Court Act for the appointment of ad hoc judges. ${ }^{49}$

The majority proves extremely sensitive to the dual functions of many constitutional rules; constitutional rules are not only meant to set up institutions and provide for their workings, they also are meant to contribute to the legitimacy of such institutions by sending the adequate signals to stakeholders. The Court thus wrote:

The purpose of s. 6 is to ensure not only civil law training and experience on the Court, but also to ensure that Quebec's distinct legal traditions and social values are represented on the Court, thereby enhancing the confidence of the people of Quebec in the Supreme Court as the final arbiter of their rights. Put differently, s. 6 protects both the functioning and the legitimacy of the Supreme Court as a general court of appeal for Canada. ${ }^{50}$

A little later, the Court goes on: “... Requiring the appointment of current members of civil law institutions was intended to ensure not only that those judges were qualified to represent Quebec on the Court, but that they were perceived by Quebecers as being so qualified." ${ }^{51}$ This clearly echoes the concerns mentioned earlier about the consequences of having a unanimous motion adopted by the National Assembly rejecting the appointment of Justice Nadon.

\section{The Dissenting Opinion on the Interpretation of Sections 5 and 6 of the Supreme Court Act}

Justice Moldaver rejected the majority's interpretation of sections 5 and 6 . He was of the view that section 6 did not add further requirements to section 5 apart from specifying that the three seats that were reserved for Quebec judges had to be filled by appointees who fulfilled section 5 requirements in Quebec institutions (i.e., the Superior Court and the

\footnotetext{
$49 \quad$ Supreme Court Reference (2014), supra, note 30, at para. 18

$50 \quad I d$., at para. 49 (underline added; emphasis in the original).

$51 \quad$ Id., at para. 56 (emphasis added).
} 
Court of Appeal of Quebec, and the Barreau du Québec, respectively, for judges and lawyers). He read no currency requirement in section 6 . He has rather harsh words for the majority's textual interpretation of sections 5 and 6 :

... Hence, for the purposes of s. 6, if it is not read in conjunction with s. 5, any member of the Quebec bar, including a newly minted member of one day's standing, would be eligible for a Quebec seat on this Court. Faced with this manifest absurdity, the majority acknowledges that the phrase "advocates of that Province" in s. 6 must be linked to the 10 -year eligibility requirement for members of the bar specified in s. 5 .

But that, they say, is where the link ends. It does not extend to the fact that under s. 5, both current and past members of the bar of at least 10 years standing are eligible. With respect, this amounts to cherry-picking. Choosing from s. 5 only those aspects of it that are convenient - and jettisoning those that are not — is a principle of statutory interpretation heretofore unknown. ${ }^{52}$

I am far from convinced that the majority actually went cherrypicking here. There is no arbitrariness in the majority's view that section 5 sets general requirements for appointment, and that section 6 says that among the pool of available candidates fitting section 5, three will also have to meet additional requirements. Sections 5 and 6 are linked, but nonetheless it makes sense that they are not identical. Would it be cherrypicking to highlight the fact that section 6 requires membership in the Barreau du Québec but section 5 does not? In fact, I venture that it may be Moldaver J. who used a heretofore unknown principle of statutory interpretation: interpreting two linked provisions as if they were identical, even if they are clearly phrased differently.

In any event, Moldaver J. agreed with the majority that " $[\mathrm{t}] \mathrm{he}$ objective of s. 6 is, and always has been, to ensure that a specified number of this Court's judges are trained in civil law and represent Quebec." ${ }^{53}$ While he also agreed with the majority that the civil law training and affiliation with the institutions mentioned in section 6 serve to protect Quebec's civil law tradition and 'inspire Quebec's confidence in [the] Court", he did "not agree that s. 6 was intended to ensure that 'Quebec's ... social values are represented on the Court' ...". ${ }^{54}$ He argues

\footnotetext{
$52 \quad$ Id., at paras. $123-124$

$53 \quad$ Id., at para. 145.

$54 \quad$ Id
} 
that to pretend that Quebec wanted to render ineligible former lawyers of at least 10 years standing is a baseless historical fabrication. ${ }^{55}$

At bottom, Moldaver J. took issue with the line-drawing exercise involved in reading section 6 the way the majority did. He could not see any reason why Quebec would oppose the appointment to the Supreme Court of a provincial court judge who had previously been a standing member of the Barreau du Québec for at least 10 years prior to being appointed to the Court of Quebec. After all, the "... Court of Québec judges apply the civil law on a daily basis". ${ }^{56}$ Justice Moldaver agreed with the majority that it is Parliament's choice to use objective criteria to draw lines that may be under-inclusive, and thus fail to achieve perfection, but he contends that when the Court determines what those are, "absurd results are to be avoided". 57

However, concluding that Parliament excluded all jurists but for those currently affiliated with the institutions mentioned in section 6 does not lead to absurd results. It leads to imperfect results, but not necessarily absurd results. Indeed, if we go down the path suggested by Moldaver J., we may also wonder what reason Quebec could have to oppose the appointment of an eminent Quebec civil law professor who had never joined the Bar. Such a highly qualified individual would nonetheless be ineligible for appointment according to both the majority's reading of section 6 and Moldaver J.'s. That does not make section 6 absurd, it simply makes it under-inclusive because it excludes individuals who may very well otherwise possess the necessary qualities to carry out the function properly.

Finally, Moldaver J. was convinced that the currency requirement does nothing to further the objective of section 6 of promoting the confidence of Quebec in the Supreme Court. ${ }^{58} \mathrm{He}$ wrote, for example: “... In Quebec, there are approximately 16,000 current members of the Quebec bar with at least 10 years standing. Surely it cannot be suggested that the appointment of any one of these 16,000 advocates would promote the confidence of Quebec in this Court." may be confusing "necessary conditions" with "sufficient conditions". He appears to be making the same mistake when he writes that "[i]n sum,

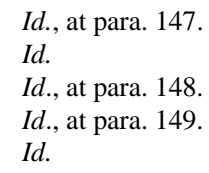


a person could have only the most tenuous link to the practice of civil law in Quebec, and yet be a current member of that bar of 10 years standing." ${ }^{60}$ We do not read the majority opinion as suggesting that the currency requirement was sufficient to promote the confidence of Quebec in the Supreme Court, nor that it ensured current knowledge of civil law. However, it was the minimal requirement that was statutorily set to frame the executive discretion in appointing judges for Quebec. Nowhere does the statute contemplate that appointment to the Supreme Court ought to be made by lottery where everyone who formally qualifies should get a ticket! That is also why Moldaver J.'s hypothetical argument about the former lawyer of 10 years' standing who would join the Barreau du Québec for a single day to be appointed must also fall flat. Let us assume, for the sake of argument, that such a lawyer may fit the formal criteria for appointment. It is far from certain that such a candidate would possess the other characteristics that would in fact convince "the people of Québec"61 that she or he is adequate to be its representative on the Bench.

\section{The Majority Opinion on the Constitutionality of Sections 471 and 472 of the Bill Entitled Economic Action Plan 2013 Act, No. 2}

Since the majority came to the conclusion that section 6 did not allow for the appointment of Justice Nadon, it also had to examine the validity of the amendment to section 6 included in Bill C-4. Indeed, the modification to section 6 of the Supreme Court Act could no longer be presented as merely "declaratory" since it aimed at excluding the requirement of contemporaneous membership to the Quebec Bar from the eligibility conditions. Were the legislative changes made validly pursuant to Parliament's legislative powers, or were they unconstitutional as an invalid attempt to modify the "Constitution of Canada in relation to" "the composition of the Supreme Court of Canada" without having obtained the consent of all 10 legislative assemblies as provided by section 41(d) of the Constitution Act, 1982?

The majority of the Court concluded that the current composition of the Supreme Court was entrenched and that

[b]oth the general eligibility requirements for appointment and the specific eligibility requirements for appointment from Quebec are

\footnotetext{
$60 \quad$ Id., at para. 150

61 See quotation accompanying note 50, supra.
} 
aspects of the composition of the Court. It follows that any substantive change in relation to those eligibility requirements is an amendment to the Constitution in relation to the composition of the Supreme Court of Canada and triggers the application of Part V of the Constitution Act, 1982. Any change to the eligibility requirements for appointment to the three Quebec positions on the Court codified in s. 6 therefore requires the unanimous consent of Parliament and the 10 provinces. $^{62}$

Section 6.1 of the Supreme Court Act (section 472 of Economic Action Plan 2013 Act, No. 2) was therefore declared to be ultra vires because it had been adopted unilaterally, without the consent of the 10 provincial legislatures. ${ }^{63}$

Justice Moldaver, while he did not need to express his views on this in light of his interpretations of sections 5 and 6 and, therefore, of the merely declaratory nature of sections 471 and 472 of the Economic Action Plan 2013 Act, No. 2, nonetheless expressly chose to state that he agreed with the majority's view that the three seats reserved on the Supreme Court is part of the "composition of the Supreme Court of Canada" and, thus, could only be modified through the unanimous consent formula of section 41(d) of the Constitution Act, 1982. However, he added that he was "not convinced that any and all changes to the eligibility requirements will necessarily come within 'the composition of the Supreme Court of Canada' in s. 41(d)." ${ }^{64}$

The conclusion that certain elements of the Supreme Court are constitutionally protected was far from self-evident since the latter was created by a mere federal statute in 1875 in accordance with Parliament's legislative power to "provide for the Constitution, Maintenance, and Organization of a General Court of Appeal for Canada" granted by section 101 of the Constitution Act, $1867 .{ }^{65}$ No explicit entrenchment of the existence of the Supreme Court in formal constitutional instruments was made before the adoption of sections 41(d) and 42(1)(d), which provide:

41. An amendment to the Constitution of Canada in relation to the following matters may be made by proclamation issued by the
41. Toute modification de la Constitution du Canada portant sur les questions suivantes se fait par proclamation du gouverneur général sous le grand sceau du

Supreme Court Reference (2014), supra, note 30, at para. 105.

Id., at para. 106.

$I d .$, at para. 115 .

65 (U.K.) 30 \& 31 Vict., c. 3 (reprinted in R.S.C. 1985, App. II, No. 5). 
Governor General under the Great Seal of Canada only where authorized by resolutions of the Senate and House of Commons and of the legislative assembly of each province:

(d) the composition of the Supreme Court of Canada; ...

42(1) An amendment to the Constitution of Canada in relation to the following matters may be made only in accordance with subsection 38(1):

$$
\text { .. }
$$

(d) subject to paragraph 41(d), the Supreme Court of Canada ...
Canada, autorisée par des résolutions du Sénat, de la Chambre des communes et de l'assemblée législative de chaque province :

$$
[\ldots]
$$

d) la composition de la Cour suprême du Canada ...;

42(1) Toute modification de la Constitution du Canada portant sur les questions suivantes se fait conformément au paragraphe 38(1) :

\section{$[\ldots]$}

d) sous réserve de l'alinéa 41(d), la Cour suprême du Canada ...

To come to its conclusions, the Court therefore had to determine that the "Constitution of Canada" contains entrenched rules about the "Supreme Court of Canada" and its "composition" - rules that could not be amended without following the proper amending formula. It could have been the case that no such rules had yet been entrenched and, therefore, that no such constitutional rules already existed (i.e., current rules regarding the Supreme Court would only have been of a statutory nature). The latter option was dubbed by the Supreme Court the "empty vessels" theory. In short, the "empty vessels" theory held that since the Supreme Court had not been constitutionalized prior to the adoption of the Constitution Act, 1982, the amendment rules were to be applicable only to entrench rules about the Court in the future, and once entrenched, the modification procedures would become applicable to such newly constitutionalized rules.

The Court disagreed with the "empty vessels" theory and declared that both the composition of the Supreme Court and the Court's "essential features" are entrenched; both require formal constitutional amendments to be modified. The majority specified the meaning of "composition" thus: "The notion of 'composition' refers to ss. 4(1), 5 and 6 of the Supreme Court Act, which codify the composition of and 
eligibility requirements for appointment to the Supreme Court of Canada as they existed in 1982." "66 The majority also declared that the "essential features" of the Supreme Court that would require formal amendment according to section 42(1)(d) of the Constitution Act, 1982, "include, at the very least, the Court's jurisdiction as the final general court of appeal for Canada, including in matters of constitutional interpretation, and its independence". 67

I must confess that I did not think that the so-called "empty vessels" theory was implausible. After all, if sections 41(d) and 42(1)(d) of the Constitution Act, 1982 provide for an "amendment to the Constitution of Canada" regarding the composition of the Supreme Court or regarding the Supreme Court itself, it makes sense to ask what, if any, rules dealing with such issues are part of the "Constitution of Canada", and to wonder how any such rules regarding the Supreme Court had found their way into the entrenched Constitution.

The majority's argument on the entrenchment of the Supreme Court is anything but formalistic. For the Court, the Statute of Westminster, combined with the end of appeals to the Privy Council in London, had the effect of putting the Supreme Court of Canada at the apex of the judicial system charged with protecting the Constitution. The Court claims that by the end of the 1970s, "the Supreme Court emerged as a constitutionally essential institution engaging both federal and provincial interests. Increasingly, those concerned with constitutional reform accepted that future reforms would have to recognize the Supreme Court's position within the architecture of the Constitution." ${ }^{\prime 68}$ The adoption of the Constitution Act, 1982 is said to have "enhanced the Court's role under the Constitution and confirmed its status as a constitutionally protected institution". ${ }^{69}$ Note here that by using the terms "enhanced" and "confirmed" instead of "established" and "entrenched", the Court suggests that constitutionalization had already happened before 1982. The Court goes on to say that section 52 of the Constitution Act, 1982 declares that the Constitution of Canada is the supreme law of the land, and "[t]he existence of an impartial and authoritative judicial arbiter is a necessary corollary of the enactment

\footnotetext{
$66 \quad I d .$, at para. 91.

Id., at para. 94.

Id., at para. 87.

Id., at para. 88 (emphasis added).
} 
of the supremacy clause" ${ }^{70}$ Citing Reference re Secession of Quebec, ${ }^{71}$ the majority repeats that "the Canadian system of government was transformed to a significant extent from a system of Parliamentary supremacy to one of constitutional supremacy". ${ }^{72}$ And therefore, the Supreme Court must assume its status as "guardian of the Constitution". ${ }^{73}$ The Court summarizes its position on its own constitutionalization by declaring that it had "gained [its] constitutional status as a result of its evolution into the final general court of appeal for Canada, with jurisdiction to hear appeals concerning all the laws of Canada and the provinces, including the Constitution" and that "[t]his status was confirmed in the Constitution Act, 1982, which made modifications of the Court's composition and other essential features subject to stringent amending procedures". ${ }^{74}$ Again, note that entrenchment is supposed to have happened as a result of "evolution" and that the Constitution Act, 1982 merely "confirmed" the Court's constitutional status.

The majority also countered the "empty vessels" theory with pragmatic arguments related to putative intentions of the framers. While the Court did not contemplate the possibility that sections $41(\mathrm{~d})$ and 42(1)(d) might have resulted from a drafting mistake, it could not fathom why the provinces would have agreed to entrench the Supreme Court's "exclusion from constitutional protection" and to "insulate this unilateral federal power [to modify the Supreme Court and its composition] from amendment except through the exacting procedures in Part V". ${ }^{75}$

This reflects two elements at the heart of the Court's pragmatic arguments. A first policy argument related to federalism leads to the conclusion that provinces could not have agreed to let Parliament "unilaterally and fundamentally change the Court, including Quebec's historically guaranteed representation, through ordinary legislation". ${ }^{76}$ Allowing Parliament to unilaterally change the institution that is ultimately in charge of arbitrating its disputes with the provinces would

\footnotetext{
$70 \quad I d .$, at para. 89.

71 [1998] S.C.J. No. 61, [1998] 2 S.C.R. 217, at para. 72 (S.C.C.) [hereinafter "Secession Reference"].

${ }_{72}$ Supreme Court Reference (2014), supra, note 30, at para. 89.

${ }^{73}$ Id., citing Hunter v. Southam Inc., [1984] S.C.J. No. 36, [1984] 2 S.C.R. 145, at 155 (S.C.C.), per Dickson J.

$74 \quad I d$., at para. 95 (emphasis added).

75 Id., at para. 98 (emphasis in original).

$76 \quad I d$. , at para. 99.
} 
change the balance of powers within the federation. It is with that danger in mind that the majority concluded that

[o] ur constitutional history shows that ss. $41(d)$ and $42(1)(d)$ of the Constitution Act, 1982 were enacted in the context of ongoing constitutional negotiations that anticipated future amendments relating to the Supreme Court. The amending procedures in Part V were meant to guide that process. By setting out in Part V how changes were to be made to the Supreme Court and its composition, the clear intention was to freeze the status quo in relation to the Court's constitutional role, pending future changes. ... This reflects the political and social consensus at the time that the Supreme Court was an essential part of Canada's constitutional architecture. ${ }^{77}$

Once this putative federal bargain was established, an implicit federal-related policy kicked in to justify the use of the static metaphor of "frozen" constitutional rules - as opposed to the dynamic metaphor of constitutional "evolution" that had led to the constitutionalization of the Supreme Court's existence. It appears that when constitutional provisions are the result of an agreement between federal partners as to how to reconcile their conflicting interests, courts should not tamper with such compromises as long as partners hold on to the importance of such a bargain. The Court recognized that "purposive interpretation ... must be informed by and not undermine that compromise". ${ }^{78}$ The reason is that courts should not create disincentives for federal partners to negotiate solutions to their conflicting interests by modifying such solutions in unpredictable ways. For example, such a policy concern appears to be at the foundation of a series of decisions about the composition and function of the Senate ${ }^{79}$ or certain religion and education rights. ${ }^{80}$ In those cases, the Court tends to avoid the "evolving" constitutional trope to refrain from upsetting the initial bargain between federal

$77 \quad$ Id., at para. 100

$78 \quad$ Id., at para. 48.

79 Reference re Legislative Authority of Parliament in relation to the Upper House, [1979] S.C.J. No. 94, [1980] 1 S.C.R. 54 (S.C.C.) and Reference re Senate Reform, [2014] S.C.J. No. 32, 2014 SCC 32 (S.C.C.) [hereinafter "Senate Reform"].

80 Adler v. Ontario, [1996] S.C.J. No. 110, [1996] 3 S.C.R. 609 (S.C.C.); Reference re Education Act (Que.), [1993] S.C.J. No. 68, [1993] 2 S.C.R. 511 (S.C.C.); Greater Montreal Protestant School Board v. Quebec (Attorney General), [1989] S.C.J. No. 19, [1989] 1 S.C.R. 377 (S.C.C.); Reference Re Bill 30, An Act to amend the Education Act (Ont.), [1987] S.C.J. No. 44, [1987] 1 S.C.R. 1148 (S.C.C.); Reference re Adoption Act, [1938] S.C.J. No. 21, [1938] S.C.R. 398, at 402 (S.C.C.), Duff J. 
partners. ${ }^{81}$ The Court may turn again to a dynamic metaphor to interpret such constitutional provisions when it senses that those provisions have taken on a life of their own - for example, when a political compromise is imagined as a fundamental civic right. ${ }^{82}$

A second policy argument related to constitutionalism led the Court to the conclusion that " $[\mathrm{t}] \mathrm{he}$ framers cannot have intended to diminish the constitutional protection accorded to the Court, while at the same time enhancing its constitutional role under the Constitution Act, 1982". ${ }^{83}$ The claim the Court made that accepting the "empty vessels" theory "would mean that the Court would have less protection than at any other point in its history since the abolition of appeals to the Privy Council" $\$ 44$ is patently false, unless the Supreme Court is arguing that it was the abolition of the appeals to the Privy Council by Parliament's An Act to amend the Supreme Court Act ${ }^{85}$ that entrenched the Supreme Court. The Court's new composition (nine judges instead of its previous six members) would also have to have been entrenched by the statute. ${ }^{86} \mathrm{Be}$ that as it may, there is nonetheless a strong policy argument in favour of ensuring the independence of the Supreme Court and protecting its powers when the constitutional constraints imposed on both the legislative and the executive branches are increased. Otherwise, such constitutional constraints may not be effective.

However, if the policy reasons given by the Court appear convincing, the how of the entrenchment of certain sections of a mere statute remains a total mystery. Through what precise constitutional mechanism were sections 4(1), 5 and 6 of the Supreme Court Act entrenched? What does the Court precisely mean by "evolution" in this context? It cannot refer to the incremental "organic growth" of the Constitution resulting from successive judicial decisions as this is not a case of extension of a series

81 See also, for example, British Columbia (Attorney General) v. Canada (Attorney General); Re An Act respecting the Vancouver Island Railway, [1994] S.C.J. No. 35, [1994] 2 S.C.R. 41, at 88 (S.C.C.).

82 Language rights used to be read mostly with some original political compromise in mind (see, for example: Société des Acadiens du Nouveau-Brunswick Inc. v. Assn. of Parents for Fairness in Education, [1986] S.C.J. No. 26, [1986] 1 S.C.R. 549, at 578 (S.C.C.)), but recent case law has recast such rights as a form of human right, and thus amenable to a more generous and purposive approach (R. v. Beaulac, [1999] S.C.J. No. 25, [1999] 1 S.C.R. 768, at paras. 24-25 (S.C.C.)).

$83 \quad$ Supreme Court Reference (2014), supra, note 30, at para. 99.

$84 \quad$ Id.

85 An Act to amend the Supreme Court Act, S.C. 1949, c. 37, s. 3 [hereinafter "Act to amend the Supreme Court Act'].

$86 \quad$ Id., s. 1 . 
of judicial precedents. Also, there is no semblance of a claim that such constitutional rules were latent within the existing body of the Constitution, simply waiting to be expounded. Quite the contrary; the Court recognizes that as a matter of constitutional law, the Supreme Court and its composition were not initially entrenched, but that they have become so entrenched through this enigmatic "evolutionary" mechanism. This is all very puzzling in light of the fact that the "crystallization of conventions" theory of entrenchment has been rejected in the Patriation Reference ${ }^{87}$ obviously prior to the adoption of the Constitution Act, 1982 - and that section 52(3) of the latter now provides that "[a]mendments to the Constitution of Canada shall be made only in accordance with the authority contained in the Constitution of Canada."

While mysterious, this "evolutionary" constitutional change is not totally unheard of in the Canadian constitutional tradition. Indeed, this is similar to how Canada achieved its independence from the United Kingdom: we know that Canada was not independent in 1867, we know that we are now, ${ }^{88}$ but we cannot tell precisely when independence happened. Canada's independence is the result of the "evolution" of its constitutional relation with the United Kingdom. This form of constitutional change is problematic if only because it falls prey to the "sorites paradox". The classic paradox can be illustrated thus: A single grain of wheat is certainly not a "heap", nor would it be a "heap" if we were to add another single grain to the first. In fact, no single grain could make the difference between something being a "heap" and something not being a "heap". Yet, we know that "heaps" exist. It is just that the boundary between something being a "heap" and something not being a heap is indeterminate; we cannot tell exactly when the grains of wheat added up sufficiently to form a "heap". The same could be said about Canada becoming independent from the United Kingdom or the Supreme Court becoming entrenched; we do not know exactly when it happened, we only know that it has happened. While the problem of vagueness is often of little or no consequence, it is troubling in the case of the entrenchment of the Supreme Court as such entrenchment entails strict

87 Reference re Legislative Resolution to amend the Constitution, [1981] S.C.J. No. 58, [1981] 1 S.C.R. 753 (S.C.C.).

88 Although debates about the appropriate ways to modify the Canadian succession rules raise the possibility that we may have thought too quickly that we were already entirely legally independent from the United Kingdom. See Philippe Lagassé \& James W.J. Bowden, "Royal Succession and the Canadian Crown as a Corporation Sole: A Critique of Canada's Succession to the Throne Act, 2013" (2014) 23 Constitutional Forum 17. 
constitutional consequences: matters that are part of the formal Constitution are, and have been, out of the reach of Parliament acting alone. It thus matters that we know when every aspect of the Supreme Court was entrenched, in order to determine whether past legislative changes to the Supreme Court Act were valid.

One may wonder if such form of "evolutionary constitutional entrenchment" could be used in the future. Are we to believe now that while the Constitution of Canada is the exhaustive source of amending procedures, Part V of the Constitution Act, 1982 does not contain all such procedures? That is, would the Constitution of Canada also allow for other amendment mechanisms like the "evolutionary constitutional entrenchment"? What are the other areas where the Constitution evolved in such a way so as to entrench what were merely statutory rules? Maybe the Supreme Court overstated the declaratory nature of the Constitution Act, 1982 and accepted only something that we could call an "implied constitutional entrenchment incidental to other constitutional changes". In other words, maybe the entrenchment of the Supreme Court was not merely the product of some obscure evolutionary process, but rather the incidental consequence of the entrenchment of sections 41(d) and 42(1)(d) after all. But if that is the case, what criteria will be used to determine whether a rule or institution is sufficiently incidental to an entrenched provision to become entrenched itself? Or, again, maybe we all got it wrong and the entrenchment of the Supreme Court happened when Parliament adopted its Act to amend the Supreme Court Act ${ }^{89}$ in 1949. But how can a mere federal statute entrench such things without having the express authority to do so? Indeed, section 101 of the Constitution Act, 1867 merely grants Parliament the power to "provide for the Constitution, Maintenance, and Organization of a General Court of Appeal for Canada, and for the Establishment of any additional Courts for the better Administration of the Laws of Canada". This is quite different from the Constitution Act, $1871^{90}$ that granted Parliament the authority ${ }^{91}$ to form new provinces from the Dominion territories outside existing provinces, ${ }^{92}$ and that provided that when such provinces were created, Parliament could no longer alter the limits of such provinces

89 Act to amend the Supreme Court Act, supra, note 85.

90 Constitution Act, 1871, (U.K.) 34-35 Vict., c. 28 (reprinted in R.S.C. 1985, App. II, No. 11 ) [hereinafter "Constitution Act, 1871"].

${ }_{91}$ This is now replaced by Constitution Act, 1982, s. 42(1)(f).

92 Constitution Act, 1871, supra, note 90, s. 2. 
without their prior consent. ${ }^{93}$ Such a constitutional mechanism effectively allowed Parliament to entrench the existence of new provinces, but there is nothing of this sort to be found in section 101 of the Constitution Act, 1867. To summarize, whatever the ultimate entrenchment mechanism involved here, the Supreme Court Reference (2014) may actually be more revolutionary than it first appears because it opens up the possibility of looking outside Part $\mathrm{V}$ for ways to operationalize formal modifications to the Constitution of Canada.

Also, while the how question of entrenchment remains open, the what question also stands out. As Robert Leckey noted,

... the Court confirmed that the sources of the Constitution of Canada now include ... parts of another federal statute, the Supreme Court Act - some provisions identified by number as well as whatever might in future be determined to embody the Court's "essential features." Indeed, by referring to the "role" that the Court has come to play, the majority judges hint that the Court's constitutionalized features may not track directly to specifiable legislative provisions, instead arising from practice. ${ }^{94}$

Thus, the majority opinion appears to recognize the entrenchment of the content of sections 4(1), 5 and 6 of the Supreme Court Act, not the sections themselves. In other words, what is actually entrenched is more fleeting than specific sections, it is a set of rules that somehow now exist independently from their legislative support. The same logic lies behind the idea that "essential features" of the Supreme Court are entrenched such features have constitutional status irrespective of the positive legislative - or maybe even regulatory or customary - form. We are now far from clear demarcation lines. The validity of Parliament's legislative action over anything related to the Supreme Court will have to be evaluated through the somewhat scholastic exercise of determining what constitutes the essence of the Supreme Court. While looking for the essence of "natural kinds of objects" like water $\left(\mathrm{H}_{2} \mathrm{O}\right)$ may be one thing, determining the essence of a man-made institution is quite another. While any such analysis will have to look at the history of the institution and its practices, ultimately what is considered its "essence" will depend on a

$93 \quad I d .$, s. 3.

94 Robert Leckey, “Constitutionalizing Canada's Supreme Court”, Int'1 J. Const. L. Blog, March 25, 2014, online: <http://www.iconnectblog.com/2014/03/constitutionalizing-canadas-supremecourt> (emphasis added). 
normative judgment about its purpose. All this is not going to enhance foreseeability about what the Constitution requires.

For a government that had made decrying judicial activism one of its trademarks, by trying to modify the Supreme Court Act, the Harper government got quite a run for its money by unnecessarily inviting the Supreme Court to analyze sections 41(d) and 42(1)(d). The government had been warned of such risks, but chose to ignore them. But if all this was not enough for the government, the Supreme Court also turned section 101 of the Constitution Act, 1867 from a power-conferring rule into a duty-conferring rule! Indeed, not only did it restrict the extent of Parliament's power to adopt laws on the Supreme Court, but it also wrote that "what s. 101 now requires is that Parliament maintain - and protect - the essence of what enables the Supreme Court to perform its current role"! ${ }^{95}$ The Court thus found that section 101 now creates positive duties for Parliament to maintain and to protect the Supreme Court.

\section{MeAning of the SuPREME CoURT REFERENCE (2014) FOR THE FUTURE OF THE SUPREME COURT OF CANADA}

The bungled process that led to the appointment of Justice Nadon to the Supreme Court and the subsequent invalidation of his nomination has not only unduly hurt him and damaged the Conservative government, it also has had important constitutional consequences. I have already outlined a few of those consequences in the previous section. However, the Supreme Court Reference (2014) will also have specific consequences for future changes to the Supreme Court. What will count as "essential features" of the Court? For example, would it be possible, without a formal constitutional amendment, to declare a section of the Court uniquely responsible for civil law appeals? If Parliament were to abolish the reference procedure, would that affect the Court's "essential features"? Could Parliament allow the Court to develop and engage in mediation procedures? While these may be difficult questions that flow from the findings of the Supreme Court Reference (2014), I will mostly comment here on the specific consequences of the entrenchment of the "composition" of the Supreme Court.

95 Supreme Court Reference (2014), supra, note 30, at paras. 98-101. 
While the entrenchment of the content sections 5 and 6 of Supreme Court Act ensures Quebec's representation on the Bench, it also entrenches the list of qualifications for Supreme Court judges. The Supreme Court Reference (2014) possibly also entrenched part of the appointment process, as the term "composition" also refers to the "action of putting together or combining; the fact of being put together or combined; combination (of things as parts or elements of a whole). ${ }^{, 96}$ The entrenchment of the three reserved seats for Quebec on the Supreme Court may certainly be seen as good news in Quebec. ${ }^{97}$ But this also means that it will be harder to formalize any stronger role for the provinces and territories in the appointment of Supreme Court judges. Indeed, a Meech-like formula may be impossible to achieve now through a simple legislative scheme. ${ }^{98}$ This limitation applies even more forcefully to any legislative attempt at enlarging the Court's composition to specifically include representatives of Aboriginal communities and territories.

Another delicate question relates to the possibility of requiring judges to be able to understand both English and French. A first bill to that effect was introduced by Yvon Godin (NDP) and passed first reading, ${ }^{99}$ but its adoption was cut short by the dissolution of Parliament and the general elections of 2008. Yvon Godin was re-elected and he introduced a new bill aimed at modifying subsection 5(1) of the Supreme Court Act to provide that: "In addition, any person referred to in subsection (1) may be appointed a judge who understands French and

\footnotetext{
96 The Oxford English Dictionary Online, s.v. "composition". The French term "composition" also has this meaning.

97 See, for example, the opinion of La Presse's Chief Editorialist André Pratte, "Un gain historique" La Presse, March 24, 2014, online: <http://www.lapresse.ca/debats/editoriaux/andrepratte/201403/24/01-4750644-un-gain-historique.php>.

98 This is not to say that the Prime Minister and the federal Minister of Justice may not develop the practice of paying close attention to the recommendations of provincial governments before selecting a Supreme Court judge. Indeed, this seems to have been the case with the appointment of Justice Clément Gascon, who was appointed to replace Justice Fish when Justice Nadon's appointment was declared invalid. See Hugo De Grandpré \& Philippe Tesceira-Lessard, "Clément Gascon nommé juge à la Cour suprême" La Presse, June 3, 2014, online: <http://www.lapresse.ca/actualites/201406/03/01-4772559-clement-gascon-nomme-juge-a-la-coursupreme.php >: “À l'Assemblée nationale, la ministre de la Justice se félicitait de voir que la voix du Québec avait été entendue, sans toutefois vouloir confirmer que le nom du juge Gascon figurait effectivement sur la liste qu'elle a soumise à Peter McKay.") In light of what has been decided in the Senate Reform, supra, note 79, it is doubtful that such a practice could be formalized.

99 Bill C-559, An Act to amend the Supreme Court Act (understanding the official languages), 2nd Sess., 39th Parl., 2008 (June 5, 2008).
} 
English without the assistance of an interpreter."100 Upon return from prorogation, Bill C-232 was reinstated ${ }^{101}$ and was finally read a third time and passed on March 31, 2009 despite being opposed by the Conservative-led minority government. ${ }^{102}$ The Conservative-controlled Senate adopted the bill on second reading and sent it to Committee on March 22, 2011. However, the Senate sat on the bill until the next election so the bill was not adopted. Yvon Godin tried a third time, ${ }^{103}$ but his Private Member's Bill was defeated on second reading by the Conservative majority on May 7, 2014. While those attempts failed under the last three Conservative governments, it is highly plausible that a future, non-Conservative, government may very well want to reopen the issue. After all, both the NDP and the PLC favoured the amendment to the Supreme Court Act. Therefore, the question remains: Is bilingualism a matter that touches upon the "composition" of the Court?

The best way to tackle the issue is to first ask whether the set of qualifications required by sections 5 and 6 represent a minimum, or maximum, set of qualifications that could be required by law? In other words, could Parliament add other qualifications without violating section 41(d)? A strong argument could be made that sections 5 and 6 are not meant to be exhaustive. For example, those sections do not require a jurist to be a Canadian citizen, to be currently a resident of Canada, to know how to read, to be mentally competent, not to be currently incarcerated for a violent crime, etc. It seems that a federal statute that would provide for at least some of those additional requirements would not run afoul of section 41(d) to the extent that those qualifications immediately refer to the actual capacities required to carry out the highest judicial functions in the land. Capacities related to the actual conduct of the judicial proceedings - i.e., capacity to read and mental competence - may be easier to justify as they are directly connected to the act of judging. Criteria related to the capacities of judges to be considered legitimate decision-makers for the political community i.e., citizenship, residence and demonstrated respect for the rule of law - may be more difficult to justify if they have the effect of impairing the

\footnotetext{
100 Bill C-232, An Act to amend the Supreme Court Act (understanding the official languages), 1st Sess., 40th Parl., 2008, cl. 1 (introduced and passed first reading November 26, 2008).

101 January 26, 2009.

102140 yeas (PLC, NDP, BQ and one independent) and 137 nays (CPC).

103 Bill C-208, An Act to amend the Supreme Court Act (understanding the official languages), 1st Sess., 41st Parl. 2011 (introduced and passed first reading June 13, 2011).
} 
ability of regions to be adequately represented. ${ }^{104}$ The additional qualifications that we have suggested here (i.e., citizenship, residency, literacy, mental competency and criminal innocence) would most certainly not impair any region's capacity to be adequately represented on the Supreme Court. While sections 5 and 6 may not set exhaustive eligibility criteria, additional requirements could probably not raise the bar on the specific criteria used by such sections. For example, section 5 could probably not be modified to require membership in a provincial bar for 25 years. Or, section 6 could probably not be modified to require that judges selected to represent Quebec must not only have been members of the Quebec Bar, but also of the bar of another province.

What then of linguistic requirements to be appointed to the Supreme Court? For one, no linguistic criterion is currently mentioned in sections 5 and 6 . Adding a linguistic criterion would therefore not count as raising the level of qualification already specifically required by such sections. Are language qualifications related to adjudicative capacities or to judicial legitimacy? While they may be related to both issues, it appears to me that it is related to judicial legitimacy, primarily as a consequence of the fact that it is a matter of adjudicative capacity. In other words, the language requirement in question is not primarily an issue related to political representation, but it is an issue that goes to the ability to fulfil one's judicial duty.

Indeed, as it would be absurd to appoint to the Supreme Court someone with no knowledge of French, or English, it would also be absurd to deny Parliament the capacity to require a working knowledge of the language in which the judge will be called to adjudicate. The problem would probably be easier to grasp for English-speakers if, instead of French, all the rules, cases and facta upon which judges are called to decide were written in Mandarin or Hindi: How could we ensure that a judge who cannot read all the relevant documents will be able to decide adequately? Being able to read the decision on appeal, all the facta presented to the Court, the statutes in their sometimes divergent linguistic versions, the relevant case law published in either of the two official languages, etc. could most probably be considered a bona fide work requirement. Indeed, let us recall that, apart from the federal court cases, judgments on appeal from the provinces are usually not translated, nor are court records of the trials. Also, facta presented to the Supreme

104 The distinction that I use here essentially tracks the distinction used by the Court between "the functioning and the legitimacy of the Supreme Court as a general court of appeal for Canada" (emphasis in the original) cited earlier, supra, note 50. 
Court are usually offered in only one language and, in fact, Quebec's Attorney General has a long-held policy to always present facta in French. The issue, therefore, is not merely one of ensuring that francophones are "represented" at the Supreme Court, it is one of ensuring that judges have the requisite capacity to carefully examine all of the documents upon which they are called to adjudicate.

In fact, the linguistic requirement may already be present in the Constitution and such legislative requirement may be merely declaratory. Indeed, an argument could be made that the constitutional principle of the "rule of law" requires that judges decide on the basis of the law - and not merely on the part of it that they can linguistically understand. As federal statutes are bilingual and neither version is fully authoritative in itself, the capacity to read both linguistic versions in conjunction is required. In other words, it would not happen that the government would have to choose between a unilingual Oliver Wendell Holmes and a merely decent bilingual candidate: no Oliver Wendell Holmes could be limited to reading only half of the law! In fact, the majority of the Court in the Supreme Court Reference (2014) itself illustrated very well the need for judges to be able to read both official versions of statutes and regulations. When interpreting different historical and linguistic versions of section 5, it wrote:

We reach the same conclusion by applying the shared meaning rule of bilingual interpretation, which requires that where the words of one version may raise an ambiguity, one should look to the other official language version to determine whether its meaning is plain and unequivocal. ... The English version of the text is unambiguous in its inclusion of former advocates for appointment, while the French version is reasonably capable of two interpretations: one which excludes former advocates from appointment, and one which includes them. The meaning common to both versions is only found in the unambiguous English version, which is therefore the meaning we should adopt. ${ }^{105}$

A judge who is unable to read "the other official language version" would simply be incapable of applying this binding rule of interpretation; he or she would not be able to carry out his or her judicial functions appropriately. The possibility of blindly relying on the legal analysis of one's colleagues - or one's law clerks — is not an appropriate substitute for the capacity to carry out judicial functions with an entirely

$105 I d$., at para. 32 (references omitted). 
independent mind. Also, it may well be that the rule of law's "right to be heard" entails the "right to be understood". Because the appealed cases are most often not translated, and because facta are not translated either, being able to read the original documents in their original language may be required in order for the right to be heard to be effective. This time, we could say that relying on colleagues and law clerks for the interpretation of the arguments presented degrades the right to be heard to a mere right to benefit from judicial hearsay.

These arguments could probably be supported by a claim that the constitutional principle of the protection of minorities requires the Supreme Court judges to be able to read all the adjudicative materials in both the language of the majority and the language of the French minority. ${ }^{106}$ The Supreme Court Reference (2014) could also inspire an argument to the effect that bilingualism of key federal institutions is an implied principle of our Constitution, and that our constitutional evolution has made this "an essential part of Canada's constitutional architecture". ${ }^{107}$ Indeed, this may be the very essence of section 20(1)(b) of the Charter. ${ }^{108}$ The promise of bilingual key federal institutions may indeed be part of the constitutional guarantee that francophones in Canada are everywhere at home.

At any rate, this shows how things are now more complicated and may give rise to unwelcome constitutional crises. If all these arguments did not work and a constitutional amendment were to be necessary to establish the requirement that Supreme Court judges must be able to understand both official languages, a veto imposed by Western provinces on a proposed amendment to ensure that francophones will be heard and understood by the top Court would most probably play into the hands of Quebec sovereigntists. And leaving the situation as it is currently is unsatisfactory, as it affects francophone views of the legitimacy of the Court and their confidence in it. Simply imagine how a litigator reacts

106 Reference re Secession of Quebec, supra, note 71.

107 Supreme Court Reference (2014), supra, note 30, at para. 100.

108 Canadian Charter of Rights and Freedoms, Part I of the Constitution Act, 1982, being Schedule B to the Canada Act 1982 (U.K.), 1982, c. 11. The subsection reads:

20(1) Any member of the public in Canada has the right to communicate with, and to receive available services from, any head or central office of an institution of the Parliament or government of Canada in English or French, and has the same right with respect to any other office of any such institution where

(b) due to the nature of the office, it is reasonable that communications with and services from that office be available in both English and French. 
when she sees a unilingual judge taking off the earpiece in which he can access simultaneous translation, knowing that the same judge has not been able to read her factum.

\section{CONCLUSION}

In my view, not only did the federal government act recklessly in making a controversial appointment to an institution whose legitimacy derives mainly from the public confidence in its impartiality and legal competence, but it also failed to respect its partners in the federation. Indeed, its unilateral modification of the Supreme Court Act resulted in negligently jeopardizing the necessary flexibility required in a cooperative federation. This brash move by the Harper government is of a piece with the attitude to federal-provincial relations that have led to the Court's opinion in Senate Reform ${ }^{109}$ and Quebec's challenge to the abolition of the gun registry that will soon be heard by the Supreme Court. ${ }^{110}$ Cooperative federalism and federal solidarity require that one government does not treat its federal partners as foreign states. When governments forget this, the Supreme Court seems willing to offer them a reminder in the form of newly discovered entrenched obligations. Such entrenched constitutional obligations, like the constitutional requirement of comity between provinces, ${ }^{111}$ have the benefit of ensuring a minimal amount of cooperation and adding constitutional protections to one party or another. But, as is the case with the entrenchment of the Supreme Court and its composition as determined in the recent reference, such new-found constitutional requirements may heavily constrain the ability of future governments to find flexible cooperative solutions to their mutual needs.

109 Supra, note 79.

Quebec (Attorney General) v. Canada (Attorney General), [2013] Q.J. No. 6676, 2013

QCCA 1138 (Que. C.A.), leave to appeal granted, [2013] S.C.C.A. No. 304 (S.C.C.).

111 Hunt v. T\&N plc, [1993] S.C.J. No. 125, [1993] 4 S.C.R. 289 (S.C.C.). 
